\title{
RECENT REGIONAL AGREEMENTS: WHY SO MANY, WHY SO MUCH VARIANCE IN FORM, WHY COMING SO FAST, AND WHERE ARE THEY HEADED?
}

\author{
JOHN WHALLEY \\ CESIFO WORKING PAPER NO. 1790 \\ CATEGORY 7: TRADE POLICY \\ August 2006 \\ Presented at CESifo Venice Summer Institute, July 2006 \\ An electronic version of the paper may be downloaded \\ - from the SSRN website: \\ www.SSRN.com \\ - from the RePEc website: \\ Www.RePEc.org \\ - from the CESifo website: \\ www.CESifo-group.de
}




\title{
RECENT REGIONAL AGREEMENTS: WHY SO MANY, WHY SO MUCH VARIANCE IN FORM, WHY COMING SO FAST, AND WHERE ARE THEY HEADED?
}

\begin{abstract}
Recent years have seen a sharp growth in the number of regional agreements both concluded and under negotiation. This paper attempts to document and discuss this growth focusing on US, EU, Chinese, Indian and other agreements. The form, coverage, and content of these agreements varies considerably from case to case. The paper asks why so many, why the variation in form, and why the recent acceleration. Implications for the trading system are discussed in a final section.
\end{abstract}

JEL Code: F1, F13.

\author{
John Whalley \\ Department of Economics \\ University of Western Ontario \\ London, Ontario N6A 5C2 \\ Canada \\ jwhalley@uwo.ca
}

June 2006

This is a paper prepared for the CESifo Venice Summer Institute on Global Economy, July 19/20, 2006. I am grateful to Shen He and to Agata Antkiewicz for comment and help with documentation. 


\section{Introduction}

In the last few years there has been a sharp growth in the number of regional trade agreements both concluded and under negotiation. Data from the WTO Committee on Regional Trade Agreements discussed below confirm this trend. Countries such as Singapore with effectively no tariff have negotiated an extensive treaty network with around 11 bilateral partners. Countries which for decades had avoided participation in regional agreements, such as Japan, have in the last 3 years initiated or concluded a growing number of agreements. Countries such as China who acceded to the WTO in 2002 and pledged themselves to multilateralism, in 2002, have within a few years negotiated 8 separated agreements ${ }^{2}$. Other countries, such as India, who for several decades limited themselves only to minimal agreements with immediate smaller neighbors have initiated or discussed bilateral negotiation with partners further away ${ }^{3}$.

This paper has two objectives. One is to understand more fully what this growth in agreements implies. They represent growing numbers of agreements across regional groupings, as well as across developed and developing countries; a widening variance in form, from initial limited framework agreements to deeper partnership agreements going well beyond trade; a sharp growth in coverage beyond goods and services into such areas as mutual recognition, competition policy, movement of persons, investment, and cooperation agreements; and a focus on trade management (or process) establishing

\footnotetext{
${ }^{2}$ See Appendix 1: Country Specific Summary Tables to Antkiewicz, Agata and John Whalley. BRICSAM and the non-WTO. CIGI working Paper No. 3, 2005.

Http://www.cigionline.org/publications/docs/BRICSAM_Non-WTO_new.pdf

${ }^{3}$ The list of India's current bilateral negotiation partners is Afghanistan, ASEAN, Bhutan, Chile, Mongolia, Nepal, Singapore, Sri Lank and Thailand. See the webpage maintained by India's Ministry of Commerce: http:// commerce.nic.in/India_rta_main.htm. And Roy, Jayanta. “ South Asian Regional Trade Agreements: Perspectives, Issues and Options.” Paper presented at the International Trade Roundtable “The WTO at 10 years- the regional Challenge to Multilateralism, Brussels, Belgium, June 27, 2005.
} 
procedures for joint exchanges, coordination and other actions as well as joint limitation on the use of trade restricting instruments ( such as tariffs). Much of this is reflected in a renaming of these agreements away from the term trade agreement towards wider forms of agreement (the recent Japan-Singapore agreement is for a New Age Economic Partnership Agreement). And the traditional Venetian focus on trade creation and trade diversion in evaluating their effects often seems irrelevant, since that the majority of these agreements involve instances where the bilateral trade at issue is small compared to the joint trade with other partners, and in many cases agreement partners are trade rivals in third markets.

The second objective is to try to attempt to make some sense of all of these developments. Why are there so many, why are they so varied, why are they occurring now? The world of the GATT at its creation in 1947 was effectively free of regional arrangements, while the world of the late 1870's was one (in Europe at least) of extensive regionalism ${ }^{4}$. I suggest that the latest wave in these agreements appears to reflect a range of factors. There is the demonstration effect of the largest trading entity in the world, the US, going regional with its lag at trading partner first in the 1987 Canadian agreement and then more broadly in NAFTA in 1991, and hence being open to regional negotiation. There is the subsequent dynamic interplay between regional and multilateral negotiation regional negotiation and agreements aiming to influence multilateral outcomes at the end of the Uruguay Round and later. Subsequently, it has been the failure of attempts to broaden multilateral negotiation into non trade areas such as competition policy and investment that have created the opportunity for regional arrangements to evolve through

\footnotetext{
${ }^{4}$ See Estevadeordal, Antoni, Brian Frantz, and Alan M. Taylor. The Rise and Fall of World Trade 18701939. NBER Working Paper No. W9318, 2002.
} 
targeted sub group negotiation. And once the wave of regionalism has been initiated, the career opportunities for negotiators completing regional agreements and the uses for politicians of trade treaties which demonstrate action to electorates has further fueled their growth.

The paper concludes by discussing the future for regional arrangements as the Doha Round draws to a seemingly minimalist and inconsequential conclusion. The paradox posed is one of regional (and primarily bilateral) agreements as seemingly left as the area of dynamism for new global integration in terms of number and coverage of agreements, while at the same time being viewed by many researchers as largely diplomatic and of limited substance relative to multilateral disciplines embedded in the WTO. 


\section{The Growth of Regional Agreements}

When the GATT was negotiated in 1947 and came into force in 1948 there were effectively no regional agreements in the world trading system. There were systems of trade preferences, most notably the commonwealth preferences agreed to at the 1932 Ottawa conference, but no formal regional trade agreements. There had in the past been extensive regional agreements in Europe, centered on the UK-France Cobden- Chevalier treaty of $1870^{5}$. This treaty had the feature that it extended to each party to the agreement the benefits of any subsequent negotiation with third parties (what today we call MFN), and became the cornerstone of an intricate system of interlinked bilateral agreements in Europe, many of which subsequent attempted to be exclusionary of other parties despite the intent of the original treaty. This system grew extensively throughout Europe prior to 1913, but with the war effectively ceased. Importantly the US position during this period was one of hostility to regional agreements which were seen as a central element of colonial power centered on Europe and from which the US had been excluded since independence.

In 1947 regional agreements were touched on only lightly in the negotiation of the GATT articles. Article 24 was agreed to allowing members to participate in regional agreements under the two conditions that broadly all trade between parties would be covered (usually interpreted since as covering at least $80 \%$ of trade) and that no barriers should be raised against third parties as a regional agreement takes effect. Article 24 was as much intended to deal with cases of dissolution of nation states (such as the 1905

\footnotetext{
${ }^{5}$ See Lazer, David. The Free Trade Epidemic of the 1860s and Other Outbreaks of Economic Discrimination. World Politics 51.4 (1999): 447-483 and Estevadeordal, Antoni, Brian Frantz, and Alan M. Taylor. The Rise and Fall of world Trade 1870-1939, NBER Working Paper No. W9318, 2002.
} 
separation of Sweden and Norway) as it was to cover new trade agreements between existing states.

The world of today is a substantial distance from 1947 as far as regional agreements are concerned. The US, the major trading power in the system, and the champion of multilateralism for the first four decades of the GATT, effectively went regional with Canada, its largest trading partner, in 1987 in an agreement initiated from the Canadian side, and later trilateralized into the NAFTA in $1991^{6}$. But since 2000 , the US has concluded Free Trade Agreements with Australia, Chile, Jordon, Omen, Morocco, Singapore, Peru, and the six Central American parties to CAFTA (Costa Rica, Dominican Republic, El Salvador, Guatemala, Honduras, and Nicaragua). The US is presently negotiating FTA's with a dozen or so further countries including Korea, Panama, Thailand, United Arab Emirates, Andean Community (Colombia, Ecuador, Peru, Venezuela), FTAA (Free Trade Area of Americas), and the SACU countries (Botswana, Lesotho, Namibia, South Africa, and Swaziland) ${ }^{7}$.

The European Union, whose formation under the 1957 Treaty of Rome provided one of the major elements of escalation of regionalism in the system, has also seen a sharp recent escalation in its regional agreements. Beginning in the 1990's previous EU development efforts focused on aid and assistance, primarily to former European colonies, began to take on the form of providing a trade, investment, and legal framework for European companies to do business in these countries ${ }^{8}$. Through a series of partnership agreements the EU approach to regional agreements has been for partner countries to

\footnotetext{
${ }^{6}$ There was an earlier US-Israel agreement in 1985, but this was more limited in scope and had geopolitical strategic underpinnings more so than primarily trade policy objectives.

${ }^{7}$ See the website of the US Government: http:// www.export.gov/fta/index.asp.

${ }^{8}$ See Kaya, Ayse. The USA's and the EU's Bilateral and Regional Trade Agreements: Divergent Paths, Divergent Ends? Working Paper 2005.
} 
adopt similar laws and policies to those in the EU that relate to both trade and the wider conduct of business. Agreements cover intellectual property, labor practices, competition policy, investment, culture, and movement of persons to the EU. Some are cooperation agreements, some association agreements, some framework agreements. In some cases they are phased agreements seen as part of possible eventual accession to the EU; in other cases they are stand alone agreements. Recent agreements span the Cotonou Agreement of 2000 with 76 African, Caribbean, and Pacific former colonies (formerly the Lome Agreement), 2002 Agreements with Algeria, Chile, Jordon, Lebanon; 2001 Agreements with Algeria, Egypt, Korea and Bangladesh, a 2004 Agreement with Syria, and a 2005 Agreement with $\operatorname{Iran}^{9}$. These agreements are in addition to the regional arrangement, reflected in the latest enlargement of the EU to 25 member states.

Elsewhere the pace of new regional arrangements has been equally rapid. Singapore, effectively a free trade zone with almost no barriers to trade, since 1998 has embarked on an extensive programme of building a network of regional agreement. Seen as cooperation agreements that go well beyond conventional trade agreements, there are now 11 of these ${ }^{10}$. China, relatively rapidly after acceding to the WTO in 2002, has concluded regional agreements and wider cooperation agreements with Hong Kong, Macau, ASEAN, New Zealand, Australia, Chile, Pakistan and the Gulf Cooperation Council, and is now negotiating with India, Singapore, and others ${ }^{11}$. Japan, long with no

\footnotetext{
${ }^{9}$ See the webpage: http:// ec.europa.eu/comm./external_relations/index.htm and http://www.acpsec.org/en/conventions/cotonou/accord1.htm.

${ }^{10}$ See Ministry of Trade and Industry, Singapore: http://app.fta.gov.sg/asp/fta/ourfta.asp. Singapore also has involved in the ongoing negotiation with Bahrain, Canada, Egypt, Mexico, Pakistan, Peru, Sri Lanka, Kuwait, Qatar and the United Arab Emirates and in ASEAN negotiation with China, Australia and New Zealand, India, Japan (in an extension to a previous agreement) and Korea.

${ }^{11}$ China also has ongoing negotiations with Thailand, APEC (Asian Pacific), East Asia (Japan, Korea), Brazil, India, Mexico, Peru, Singapore, SACU (South Africa), Mercosur (South America), Iceland, Japan and Korea.
} 
regional agreements now has a series of concluded agreements with Singapore, ASEAN and others. India is a further country joining this trend with new regional agreements with ASEAN and Singapore.

As of September 2005, 334 regional trade agreements had been notified to the WTO committee on regional trade agreements, and of those notified 183 were still in force. Crawford and Fiorentino (2005) document this growth in notifications in the GATT from 0 between 1943 and 1957, and calculate that by 2008, if RTAs, at a negotiation, proposal, or actually signed (but not yet notified) stage are included the number of agreements in force will grow to 300. Crawford and Fiorentino also include in their paper global maps showing the frequency (number) of agreements with 30 or more agreements in some European countries, most of North America and Latin America with 10-19 agreements, and other regions between 4 and 10. By any stretch of the imagination this constitutes a sharp and recent acceleration in regionalism in the trading system.

However, evaluating both its content and significance is a daunting task. Some agreements relate to bilateral or regional links where trade flows and other forms of economic interaction are limited (India-Afghanistan, US-Oman), others apply to cases where linkages are deeper. Some agreements seem to be token sane while others are more substantive. Moreover, WTO multilateral disciplines remain as the anchor of the trading system, and how far these agreements go beyond what is already implied by WTO agreements is of unclear. Since WTO negotiating rounds have progressively lowered bound tariffs, it is often assumed the scope for substantive regional agreements with impact in the tariff sphere has become more limited. 
This wide variation in form and circumstance leads to sharply divergent evaluations of their impact. One school of though highlights the increasing difficulties in the WTO Doha Round and its likely minimalist outcome, along with the growing difficulties of dispute settlement in multilateral process. It thus sees this growth in regionalism potentially as the leading edge of future negotiated global integration. But the contrary view suggests that many are negotiated for diplomatic reasons or even personal advancement of negotiators, and/or politicians. The characterization is one of bilateral froth sitting on top of substantive multilateralism. It also highlights the much larger potential number of bilateral agreements (Factorial 180) then those we actually now have $^{12}$

Neither simple characterization is, in my view, appropriate; both have elements of plausibility and both need to be considered given that few substantive evaluations of individual agreements exist in the literature where both the texts of agreements and their substantive content are jointly evaluated. The use of gravity or GTAP models for the analysis of impacts of the tariff barrier change components may yield little if the agreements are complex and elaborate. A recent World Bank (Global Economic Prospects 2005) estimate is that perhaps around $43 \%$ of world trade was covered by agreements in force in 2003 and was projected to increase to 55\% by 2005 (OECD, $2003)^{13}$. But such calculations only raise more questions. How large are the impacts of these agreements on covered trade ${ }^{14}$ How large are the preference margins in these

\footnotetext{
${ }^{12}$ With 191 UN countries, if the potential number of agreements is factorial 191, this yields $1.85 \mathrm{E}+354$.

${ }^{13}$ See the World Bank. Global Economic Prospects-Trade Regionalism, and Development 2005 OECD, Regionalism and the Multilateral Trading System- The Role of regional trade agreements, Policy Brief, 2003.

${ }^{14}$ In the case of Canada - US trade there are estimates that perhaps $70 \%$ of bilateral trade eligible for preferential tariff treatment takes place without eligible preferences being claimed because MFN tariffs are
} 
agreements compared to no agreement situations? How significant are the non trade components of these agreements in a range of newly covered areas (services, IP, investment, movement of persons, mutual recognition, and competition policy).

any way low and the costs of establishing origin p are often prohibitively large for exporters. See policy Research Initiative Discussion Paper June 2005, P 16. 


\section{An Overview of the Content of recent regional agreements}

Evaluating both the impact of and potential future significance of recent regional agreements, in my view, requires some form of synthesis of what these agreements actually are since most go well beyond the tariff barrel agreements studied by economic theorists. By way of example the 2002 US-Singapore bilateral agreement is 210 pages of text and 1375 pages of annexes; with a 299 page annex on rules of origin ${ }^{15}$. The 1987 Canada-US bilateral agreement contains 23 chapters and covers a wide range of items including energy security, financial services, wine and spirits, special dispute settlement covering bilateral use of anti dumping and countervailing duties, compensation for losses to foreigners from government actions, and other matters ${ }^{16}$.

One way to approach these agreements is as tariff plus agreements, and recognize that in many cases the plus component dominates the tariff part in length of text and likely in significance given that in many cases the MFN tariff rates are sufficiently low that the margins of preference involved have limited impacts on trade.

But a further element in assessing these agreements is to recognize their significance as process rather than simply instrument based agreements that limit the use of trade based interventions (tariffs). The 1957 Treaty of Rome set out a road map for ever deeper integration in Europe moving initially from joint tariff removed among partners on to a tax union and eventually to economic and monetary union a common currency, a common budgetary and competition policy structure, and beyond. As such it stands in sharp contrast to the 1991 NAFTA which is a one off agreement that does not set out an ongoing process for North American economic integration.

\footnotetext{
${ }^{15}$ See http://www.ustr.gov/Trade_Agreements/Bilateral/Singapore_FTA/Final_Texts/Section_Index.html. ${ }^{16}$ See http://wehner.tamu.edu/mgmt.www/NAFTA/fta/index.htm.
} 
Several in recent regional agreements, and especially those of China and Japan, are centrally labeled as cooperation and partnership agreements. Commitments are set out to cooperate in tourism, rural development, standards setting, and in other areas including poverty alleviation and the promotion of mutual understanding. Tariff arrangements are thus but one part of these agreements. Some agreements also contain broad commitments to cut tariffs, but with details to be subsequently negotiated. In some cases, agreements on rules of origin, and even bilateral dispute settlement are to follow the concluded broad agreements ${ }^{17}$. And the move into newer areas not covered by current WTO disciplines (or current or prospective negotiations) such as standards setting, competition issues, mutual recognition and other areas is reflected in the language used to label agreements. The recent Japan-Singapore agreement is a "New Age Economic Partnership” agreement, for instance; and the China-ASEAN agreement is a Framework Agreement on Comprehensive Economic Cooperation ${ }^{18}$.

Having noted this tendency for regional agreements to evolve as formalized management arrangements for bilateral economic interaction, more so than treaty based agreements to mutually limit the use of border measures, a further striking feature is the diversity among the agreements themselves.

In part this is reflected in the sharply differing focus of agreements across the partners involved. Many are agreements between countries of sharply asymmetric size, and these agreements often follow a seemingly standardized pattern common to other agreements involving the larger partner. For instance, both US and EU agreements typically follow a standard pattern and form. In contrast, China's recent agreements (see Antkiewicz and

\footnotetext{
${ }^{17}$ For example, the China-ASEAN Framework Agreement on Comprehensive Economic Cooperation. See www.aseansec.org

${ }^{18}$ See ASEAN website: http://www.aseansec.org/4979.htm.
} 
Whalley (2005)) seem to be more customized to individual partners and perceived Chinese opportunities in each bilateral negotiation.

US agreements are perhaps most simply characterized as following an architecture in which the central element offered from the US side is bilateral elimination of remaining industrial tariffs (or effectively acceleration of what may be anticipated to subsequently occur multilaterally). This is viewed from the US side as proportionally more beneficial to the smaller partner, and so in return what is typically requested is what usually amounts to unilateral liberalization in key service sectors (banking, insurance, telecoms) ${ }^{19}$ by the smaller partners. These elements of liberalization are then qualified (rules of origin, safeguards, sectoral exemptions) and new elements added to these agreements going beyond tariffs on industrial products and commitments in services (IP, competition) ${ }^{20}$. They are seen as one off agreements, and among the present set of agreements globally, perhaps least process oriented.

EU agreements differ substantially from US agreements. Most have their origins in changes in thinking in the European Commission in the early 1990's that relationships with former colonies need to evolve away from aid and direct assistance and more towards arrangements allowing for easier transactions for European business with these states. This is seen as a source of mutual benefit; both development enhancing and pro European business. Thus the focus of these agreements is jointly on improving access to these markets by removing or weakening border measures and improving the environment for European business once inside the national border. Legal structure,

\footnotetext{
${ }^{19}$ Key service sectors also include: computer and related services, energy, etc. see the website of Vietnam Government. http:// www.vietnamembassy-usa.org/news/story.php?d=20060515105449\&print=yes

${ }^{20}$ See the World Bank study http://www.bilaterals.org/article.php3?id_article=984; the report from Third World Network http:// www.twnside.org.sg/title2/par/mk005.doc and http://www.ustr.gov/Trade_Agreements/Section_Index.html
} 
competition policy, standards, and other such arrangements are all key. EU agreements, in turn, and in contrast to US agreements, are characterized by a series of hierarchical partnership agreements through which partner countries can progress. In some cases this is seen as part of the transitional process to eventual EU accession. EU agreements have been dominated since the 1990’s by agreements either with former Soviet republics and with former colonies, but in the last 5 years agreements with partners outside this group of countries have been added, most notably with Mercosur and with South Africa. These agreements take on a somewhat different form reflecting both the different bargaining power and interests of these partners.

Elsewhere, China's agreements negotiated since accession to the WTO are quite different one from another and seemingly customized to each partner. No common template is involved. Singapore sees itself as the hub for an emerging network of regional agreements (even with effectively zero tariffs) which centrally involve intellectual property, product standards and other matters. India has begun active regional negotiation outside South Asia ${ }^{21}$. Chile, Canada, and others are all active.

A feature of many of the larger country agreements is the seeming clear tie in both to multilateral negotiating process, and also the use of sequential bilateral or regional negotiation. For instance, the failure of the 1990 ministerial in Brussels meant to conclude the GATT Uruguay Round on schedule was followed within a week by a US declaration to launch regional negotiations in the Western hemisphere as a way of exerting pressure on the EU and others for multilateral conclusion. Also, as a further

\footnotetext{
${ }^{21}$ India's current engagement in bilateral negotiation include ASEAN, Singapore, Thailand Malaysia, Indonesia, SACU, Chile, Mauritius, GCC, MERCOSUR, BIMSTEC, Afghanistan, Bhutan, Nepal, Sri Lanka (Korea, Japan, Chin-joint study group). See http://commerce.nic.in/india_rta_main.htm Chile’s engagement in RTA regional negotiation includes Argentina, Bolivia, Canada, Central America, Colombia, Ecuador, EFTA, EU, Korea, Mercosur, Mexico, New Zealand-Singapore-Brunei, Peru, US and Venezuela.
} 
example the US seemingly first negotiated bilateral agreements with the seeming simple cases of Chile and Singapore before moving onto larger partners. Singapore was largely duty free, and Chilean exports to the US were largely of copper and out of season fruit and vegetables. Establishing precedents in early regional forms of agreements, made it easier to move on to a second set of larger entities; Australia, Morocco, CAFTA, SACU; presumably with the intent of eventually approaching larger negotiations such as Mercosur , India, or China with an established treaty network in place. The EU, also notably, has yet to conclude regional agreements (with the exception of Mercosur) with its most significant non European /non colonial entities. The content of each regional agreement in part this seemingly reflects a dynamic bargaining process involving many agreements in the entire sequence. 


\section{Beyond Goods and Services; the example of ASEAN and ASEAN countries} agreements. $^{22}$

Many of the agreements which make up the wave of recent RTA's go substantially beyond conventional free trade agreements in dealing with items not yet subject to WTO disciplines and viewing FTA's as still largely concerned with goods and services is no longer in keeping with contemporary realities. They have instead, like multilateral WTO negotiations, become platforms for packaging a range of new and ongoing issues previously dealt with separately (such as visas / work permits) into a combined negotiation. These additional issues added to the trade negotiation differ both between multilateral and regional negotiations, and across individual regional negotiations.

The number and complexity of these agreements makes synthesizing their features a non-trivial task, and so I now discuss only a subset of recent agreements involving both ASEAN as a single entity, and individual ASEAN countries negotiating separately (Malaysia, Thailand and Singapore). ASEAN at this point has concluded three formal framework agreements (with China, Japan, and India) and aims to active more substantive arrangements and has a further 2 (with Korea, and Australia \& New Zealand jointly) under negotiation. Singapore has concluded 6 substantive agreements (with the US, EFTA, Australia, New Zealand, Japan and Jordan) and is negotiating a further 12. Thailand has concluded 2 full agreements (with Australia, Bahrain), 2 framework agreements (with the US, India), 1 ancillary agreement to a wider ASEAN agreement only covering vegetable and fruits (with China), and is negotiating a further 5 agreements. Malaysia has a single bilateral investment treaty with the US, but is negotiating a further

\footnotetext{
${ }^{22}$ This section draws in part on Dayaratna Banda and Whalley (2006).
} 
5 agreements. These agreements vary greatly in length, specificity and coverage; some are detailed with substantial specificity (especially the Singapore-US agreement).

What is striking about them as a set is their breadth of coverage. Several areas beyond current WTO disciplines are dealt with including competition policy, mutual recognition (both of professional qualifications and product standards and testing), movement of persons and visa/work permit arrangements, investment, and cooperation in specific areas.

Of the ASEAN blocwide and regional agreements, six contain provisions relating to competition policy; Singapore-US, Singapore-EFTA, Singapore-New Zealand, Singapore - Australia, Singapore-Japan, and Thailand-Australia. The two ASEAN agreements (with China and India) have no coverage of competition policy. Singapore at the time of negotiation with the US had no formal competition law, but is now in the process of enacting such laws.

The ways in which competition policy is dealt with in these agreements varies from case to case. The most detailed treatment occurs in the Singapore-US agreement, and is set out in a 8 page chapter (12) not titled competition policy but instead "Anti Competitive Business Conduct, Designated Monopolies and Government Enterprises”. This chapter commingles broad statements of principles on matters related to competition policy and detailed and specific commitments by the two parties on a range of competition related matters.

Other agreements cover competition in less detail, and with some variation. The Thai-Australia agreement commits both governments to actually apply their competition laws, but allows measures or sectors to be exempt from commitments on public interest 
grounds if done in a transparent way. The Singapore-Australia agreement is similar but goes a little further. The Singapore-EFTA agreement is even shorter, comprising 11 lines of text (in chapter 10).

The competition policy component of these agreements can be seen as a partial bilateral response to the failure in the WTO to negotiate on competition policy. In the WTO these was considerable discussion of competition related issues following the 1996 Singapore ministerial and prior to the launch of the Doha Round. As Bhattacharjea (2004) identifies, the directions proposed for a multilateral agreement in competition policies in these discussions included achieving investment promoting benefits of harmonized competition policies; actions against anti competitive practices that restrict market access for imports; replacement of anti-dumping arrangements by competition policies (as in the EU); and restrictions on cross border cartels. In the 2001 agreement to launch the round only part of this list survived, and this remaining part was then dropped at the 2004 Cancun ministerial (see Bhattacharjea 2004) ${ }^{23}$.

Investment is dealt with in more of the country agreements than is competition policy and is also covered in the ASEAN agreements. There is also more commonality in approach, with central commitments being (either or both) National Treatment and MFN treatment for foreign investors (typically) alongside provisions relating to expropriation, compensation, and (in some cases) repatriation of earnings.

The ASEAN - Japan and ASEAN - India agreements are virtually the same and contain general commitments to create a liberal and competitive environment for investment, to strengthen cooperation in investment, improve transparency of laws and

\footnotetext{
${ }^{23}$ Bhattacharjea, A. (2004), “ Trade and Competition Policy”, Working Paper No 146 Indian Council for Research on International Economic Relations, Delhi.
} 
regulations, and to protect investors. The ASEAN-China agreement has similar general provisions, but the language differs.

The Thai-Australia agreement begins with definitions but then centers its liberalization commitments on most favoured nation treatment for investors, with separate "pre-establishment” and "post-establishment” national treatment provisions. ${ }^{24}$ There is then language relating to the promotion and protection of investments, and provisions relating to expropriation and compensation for losses as well as access to dispute settlement.

These agreements show much more commonality of approach for investment than is the case of competition policy. There are substantive commitments, and interestingly of relatively similar form to those proposed for the failed Multilateral Agreement on Investment. In this area, regional negotiations clearly seem to be fulfilling the role of a partial substitute for a wider multilateral agreement between countries who were not (in the main) forces of resistance to a possible agreement on multilateral disciplines in the WTO.

Issues related to mutual recognition in these agreements arise under a number of chapter headings in the various texts. Issues of product testing and standards are in chapters on technical barriers to trade and sanitary and phytosanitary restrictions, and particular sectoral chapters, such as telecommunications, touch on product standards while chapters on services deal with recognition of professional certification. This treatment of mutual recognition differs substantially from the explicit pairwise country treaties on mutual recognition that have been negotiated in recent years. These typically

\footnotetext{
${ }^{24}$ The rationale for these two separate commitments as against a single national treatment commitment is not clear to the present authors.
} 
involve both mutual agreement to accept agreed competent authorities for the mutual determination of standards, and agreements on the mutual recognition of more narrowly specified items (such as notorial attestations, or certificates).

The ASEAN blocwide and country agreements also deal with issues related to movement of persons and usually in separate chapters. This is reflective both of the growing significance of visa and work permit issues in the global economy and the absence of multilateral venues for dealing with them (see $\mathrm{Ng}$ and Whalley 2004). ${ }^{25}$ In this case, country or regional agreements provide the platform for adding an issue under current discussion, but with no clear multilateral forum for discussion. Bargaining across issues and with it, the greater probability of achieving results presumably provides the rationale for this.

The Singapore-US agreement begins with a broad statement that the preferential trading relationship between the parties implies comparable temporary entry with transparent criteria and procedures. It then proceeds to a general obligation to apply measures in the area so as to avoid adverse impacts or delays involving trade in goods and services or the conduct of investment activities under the agreement. There are then provisions on information exchange, transparency criteria and an agreement to appoint temporary entry coordinators in each country.

The detailed substance occurs in an annex (11A) which sets out details of arrangements under four section headings; business visitors, traders and investors, intracompany transfers, and professionals. In some cases, (such as business visitors) it sets out required documentation for entry. In other categories (professionals) there are appendices

\footnotetext{
${ }^{25}$ Also, see Nielson (2002) for a recent discussion of temporary movement of persons in other recent bilateral agreements.
} 
which set out numerical target for initial applications for entry of business persons from Singapore that US shall annually approve $(5,400)$. These also specify a number of considerations required by US immigration laws can that the US shall not take into account when making entry visas.

The ASEAN agreements also contain a range of commitments relating to cooperation in a number of areas. Cooperation agreements are typically vague in statement and it may be tempting to dismiss them as lacking in substance. But they do represent a commitment to a deepening of bilateral relationships and in specific and designated areas and hence are of substance from a process point of view.

The stress on cooperation in the China-ASEAN agreement is manifest in the title of the agreement as a "Framework Agreement on Comprehensive Economic Cooperation” indicating the significance attached to cooperation in bilateral relationship building in this case. There are commitments to strengthen cooperation in 5 key sectors (agriculture, information and communication technology, human resource development, investment, and Mekong River basin development).

The ASEAN agreement with Japan and India also details many areas of cooperation including trade facilitation, business environment, energy, information and communications technology, human resource development, tourism and hospitality, transportation and logistics, and standards conformity and mutual recognition.

Though inevitably vague and hard to interpret as legal text, these cooperation elements play a role as process in the deepening of country to country relationships in these agreements. For countries where sequential relationship building and deepening is seen as a critical way to proceed in international negotiations, the cooperation provisions 
of these agreements can play a major role through process as far as international economic management is concerned. Commitments to cooperate, even if ill defined, are part of process and these new partnership agreements unlike traditional tariff based trade agreements are not typically negotiated as one off treaty arrangements by countries with an exclusive focus on legal provisions and detailed text. 


\section{Why So many, Why so much variance inform, why coming so fast, and where are they headed?}

This latest wave of regional agreements which have spread so quickly through the trading system does not, in my view, reflect a single dominant influence. Instead, a series of factors need noting to account for the phenomena.

First, their complexity seems to reflect the relative ease of customizing agreements to cover non trade barrier issues in ways acceptable to the two parties so as to avoid a lowest common denominator outcome from common multilateral agreements. Thus, two countries may choose to cover, say, competition policy or investment in their pairwise agreement even if other countries are unwilling to negotiate in the area and bilaterally they can cover such an issue in a way which differs from that of any other bilateral pair.

As such, one can argue that the attempt multilaterally in the WTO to first deal with an expanded agenda beyond conventional trade issues such areas as environment, competition policy, labor standards, and investment (the so called Singapore issues, after Singapore 1996), and its subsequent failure as these issues first fell in profile and then were withdrawn from the Doha Round agenda has resulted in renewed efforts bilaterally. Conventional tariff based RTA's thus provide a convenient platform to which there non trade issues can also be appended bilaterally and these issues can vary from case to case.

Second is the linkage to multilateral process. If multilateral process seems slowed or stalled, and in the tariff area has seemingly removed much of the room for further negotiation, then regional negotiation may seem the way forward. Global cooperation in trade may be viewed as having moved from some form of non-cooperative Nash 
equilibrium in the 1930's to cooperation with low tariffs (at least in the OECD) by the end of Uruguay Round. If multilateral cooperation subsequently attempts to move into non trade areas and fails due to its complexity and its rule writing rather continuous instrument use limitation nature; then RTA's can fill the void. And if attempts to revive a failing multilateralism involve the use of RTA's as a form of pressure on multilateral process then RTAs will accelerate.

Third is the behaviour of the large powers in the trading system. In 1947 there were no regional agreements. The 1957 creation of the EEC (and subsequently the EU) allowed by the GATT members created a regional entity. The acceptance by the US in 1987 of Canadian overtures for a bilateral agreement, and the demonstration that the largest trading entity in the system had gone regional with its largest trading partner changed perceptions as to the commitment of the system's central player to multilateralism. And with the formation of APEC in 1994, in part as the non EU coalition to force a conclusion to the Uruguay Round, the central presence of regionalism in the system was clearly established.

The pursuit since the early 1990's of regional agreements by smaller powers with larger powers has been accelerated by demonstration that the larger powers were now willing to proceed regionally. The GATT as it grew after 1957 with the formation of the EU through the Kennedy and Tokyo Rounds can be seen, in effect, as a form of bilateral accommodation between the two largest entities in the trading system which through MFN also applied to third entities most of whom had their dominant trade with either the US or the EU. Multilateralism in the GATT can be viewed as a peace treaty between the US and the EU that they would mutually extend whatever they negotiated with third 
parties to each other. The later rise of Japan and its accommodation within this system as a multilateral non regional entity preserved its structure until the late 1980s.

In the late 1980's, things begin to change. The US first regional went with Canada, and then with NAFTA. The Uruguay Round proved hard to conclude and regional negotiation was in part used as a mechanism to try to achieve multilateral closure. The Doha Round then became hard to launch, and harden to conclude. The subsequent attempt to the broaden the bargaining in the WTO to non trade areas failed, but the demand for such negotiation remained. Driven by their desire to be inside blocs, smaller countries then seek safe haven agreements. RTAs become acceptable currency and as a platform for wider use their coverage grows.

Finally comes the role of opaque RTAs in domestic and international political process, Negotiating RTAs provides potential significant career enhancement to negotiators, and long, complex and hard to interpret RTA's even provide a collusive outcome for negotiators jointly seeking to advance careers. Politicians can use RTA's domestically to show their activisms and publicize their achievements, even if vague and lacking in concreteness. In their international dialogue with each other, those in bureaucracies in countries can use the machinery of RTAs and all of the ongoing consultation established as advancement from a process point of view in trade management.

The net result has been sharp growth and acceleration in RTA's of the form and extent set out earlier. Where is the process headed? To some degree the jury is still out. If the content of these RTAs remains vague, the agreements primarily are diplomatic arrangements negotiated for geopolitical linkage rather than significant economic impact. But agreements do invoke substantive economic relationships and their coverage is broad. 
Where they head may as much as anything be determined by what happens multilaterally. If, as most expect, the Doha Round concludes with a minimal outcome, dispute settlement in the WTO weakens, and multilateral disciplines are perceived to weaken, then regionalism as the central form of policy coordination in the system will grow. And if into non OECD trade continues grow at its current high rates (China is now India's $2^{\text {nd }}$ largest export market), the desire for trade management of these relationships will grow. Weakening multilateralism seemingly inevitably leaves a growing patchwork quilt of regional policy cooperation as the ever more prominent component of the system. 


\section{Conclusions}

In this paper I seek to both characterize and assess the recent wave of regional agreements in the trading system which has accelerated since 2000. Nearly 400 agreements now exist, and by 2008 according to WTO analyze a significant number of countries will be party to more than 30 agreements. I suggest these agreements are characterized by several central features; substantial diversity in form, broadened coverage of issues to the degree that RTAs seemingly now provide a platform to which a range of issues are appended; vagueness in language and commitment so that they should be understood as much as process agreements as mutual limitations on trade restrictions measures; and in may cases sharp asymmetries of partner size.

I suggest that a number of factors account for growth in these agreements. These include the use of RTAs as a platform to append a range of issues for targeted bilateral negotiation; the failure of multilateral negotiation to extend bargaining to non trade issues point Uruguay Round; the prospect of limited failure multilateral process; the demonstration effect of large entities going regional and smaller entities seeking safe haven agreements with their most important large partners; and the uses of agreements by politicians and negotiators to demonstrate action and negotiation seeking advancement.

I conclude by suggesting that weakened multilateralism after a minimalist conclusion to the Doha Round may well only accelerate this process. 


\section{Reference}

Antkiewicz, A. and J. Whalley (2004), “China’s New Regional Trade Agreements” The World Economy, Vol 28. No. 10..

Antkiewicz, A. and J. Whalley (2004), "BRICSAM and the non WTO” (forthcoming), Review of International Organization.

Crawford, J and R. V. Fiorentino (2005), “ The Changing Landscape of Regional Trade Agreements”, WTO Discussion Paper, No. 8.

Dayartna Banda O.G and J. Whalley (2006), “Beyond Goods and Services: Competition Policy, Investment, Mutual Recognition, Movement of Persons, and Broader Cooperation Provisions of Recent FTAs Involving ASEAN Countries”, mimeo, University of Western Ontario.

Ng E. and J. Whalley (2004), "Visas and Work Permits: Can GATS/WTO Help or is a New Global Entity Needed?”, mimeo, University of Western Ontario.

Policy Research Initiative, Gov’t of Canada (2005), Nafta Rules of Origin, Discussion Paper.

WTO (2004), Report of the Committee on Regional Trade Agreements to the General Council, WT/REG/14, Nov 24, 2004. 
World Bank (2003), Global Economic Prospects 2003; Trade, Regionalism and Development; Washington, World Bank. 


\section{CESifo Working Paper Series}

(for full list see www.cesifo-group.de)

1728 E. Maarten Bosker, Steven Brakman, Harry Garretsen and Marc Schramm, A Century of Shocks: The Evolution of the German City Size Distribution 1925 - 1999, May 2006

1729 Clive Bell and Hans Gersbach, Growth and Enduring Epidemic Diseases, May 2006

1730 W. Bentley MacLeod, Reputations, Relationships and the Enforcement of Incomplete Contracts, May 2006

1731 Jan K. Brueckner and Ricardo Flores-Fillol, Airline Schedule Competition: ProductQuality Choice in a Duopoly Model, May 2006

1732 Kerstin Bernoth and Guntram B. Wolff, Fool the Markets? Creative Accounting, Fiscal Transparency and Sovereign Risk Premia, May 2006

1733 Emmanuelle Auriol and Pierre M. Picard, Government Outsourcing: Public Contracting with Private Monopoly, May 2006

1734 Guglielmo Maria Caporale and Luis A. Gil-Alana, Modelling Structural Breaks in the US, UK and Japanese Unemployment Rates, May 2006

1735 Emily J. Blanchard, Reevaluating the Role of Trade Agreements: Does Investment Globalization Make the WTO Obsolete?, May 2006

1736 Per Engström and Bertil Holmlund, Tax Evasion and Self-Employment in a High-Tax Country: Evidence from Sweden, May 2006

1737 Erkki Koskela and Mikko Puhakka, Cycles and Indeterminacy in Overlapping Generations Economies with Stone-Geary Preferences, May 2006

1738 Saku Aura and Thomas Davidoff, Supply Constraints and Housing Prices, May 2006

1739 Balázs Égert and Ronald MacDonald, Monetary Transmission Mechanism in Transition Economies: Surveying the Surveyable, June 2006

1740 Ben J. Heijdra and Ward E. Romp, Ageing and Growth in the Small Open Economy, June 2006

1741 Robert Fenge and Volker Meier, Subsidies for Wages and Infrastructure: How to Restrain Undesired Immigration, June 2006

1742 Robert S. Chirinko and Debdulal Mallick, The Elasticity of Derived Demand, Factor Substitution and Product Demand: Corrections to Hicks' Formula and Marshall’s Four Rules, June 2006 
1743 Harry P. Bowen, Haris Munandar and Jean-Marie Viaene, Evidence and Implications of Zipf's Law for Integrated Economies, June 2006

1744 Markku Lanne and Helmut Luetkepohl, Identifying Monetary Policy Shocks via Changes in Volatility, June 2006

1745 Timo Trimborn, Karl-Josef Koch and Thomas M. Steger, Multi-Dimensional Transitional Dynamics: A Simple Numberical Procedure, June 2006

1746 Vivek H. Dehejia and Yiagadeesen Samy, Labor Standards and Economic Integration in the European Union: An Empirical Analysis, June 2006

1747 Carlo Altavilla and Paul De Grauwe, Forecasting and Combining Competing Models of Exchange Rate Determination, June 2006

1748 Olaf Posch and Klaus Waelde, Natural Volatility, Welfare and Taxation, June 2006

1749 Christian Holzner, Volker Meier and Martin Werding, Workfare, Monitoring, and Efficiency Wages, June 2006

1750 Steven Brakman, Harry Garretsen and Charles van Marrewijk, Agglomeration and Aid, June 2006

1751 Robert Fenge and Jakob von Weizsäcker, Mixing Bismarck and Child Pension Systems: An Optimum Taxation Approach, June 2006

1752 Helge Berger and Michael Neugart, Labor Courts, Nomination Bias, and Unemployment in Germany, June 2006

1753 Chris van Klaveren, Bernard van Praag and Henriette Maassen van den Brink, A Collective Household Model of Time Allocation - a Comparison of Native Dutch and Immigrant Households in the Netherlands, June 2006

1754 Marko Koethenbuerger, Ex-Post Redistribution in a Federation: Implications for Corrective Policy, July 2006

1755 Axel Dreher, Jan-Egbert Sturm and Heinrich Ursprung, The Impact of Globalization on the Composition of Government Expenditures: Evidence from Panel Data, July 2006

1756 Richard Schmidtke, Private Provision of a Complementary Public Good, July 2006

1757 J. Atsu Amegashie, Intentions and Social Interactions, July 2006

1758 Alessandro Balestrino, Tax Avoidance, Endogenous Social Norms, and the Comparison Income Effect, July 2006

1759 Øystein Thøgersen, Intergenerational Risk Sharing by Means of Pay-as-you-go Programs - an Investigation of Alternative Mechanisms, July 2006 
1760 Pascalis Raimondos-Møller and Alan D. Woodland, Steepest Ascent Tariff Reforms, July 2006

1761 Ronald MacDonald and Cezary Wojcik, Catching-up, Inflation Differentials and Credit Booms in a Heterogeneous Monetary Union: Some Implications for EMU and new EU Member States, July 2006

1762 Robert Dur, Status-Seeking in Criminal Subcultures and the Double Dividend of ZeroTolerance, July 2006

1763 Christa Hainz, Business Groups in Emerging Markets - Financial Control and Sequential Investment, July 2006

1764 Didier Laussel and Raymond Riezman, Fixed Transport Costs and International Trade, July 2006

1765 Rafael Lalive, How do Extended Benefits Affect Unemployment Duration? A Regression Discontinuity Approach, July 2006

1766 Eric Hillebrand, Gunther Schnabl and Yasemin Ulu, Japanese Foreign Exchange Intervention and the Yen/Dollar Exchange Rate: A Simultaneous Equations Approach Using Realized Volatility, July 2006

1767 Carsten Hefeker, EMU Enlargement, Policy Uncertainty and Economic Reforms, July 2006

1768 Giovanni Facchini and Anna Maria Mayda, Individual Attitudes towards Immigrants: Welfare-State Determinants across Countries, July 2006

1769 Maarten Bosker and Harry Garretsen, Geography Rules Too! Economic Development and the Geography of Institutions, July 2006

1770 M. Hashem Pesaran and Allan Timmermann, Testing Dependence among Serially Correlated Multi-category Variables, July 2006

1771 Juergen von Hagen and Haiping Zhang, Financial Liberalization in a Small Open Economy, August 2006

1772 Alessandro Cigno, Is there a Social Security Tax Wedge?, August 2006

1773 Peter Egger, Simon Loretz, Michael Pfaffermayr and Hannes Winner, Corporate Taxation and Multinational Activity, August 2006

1774 Jeremy S.S. Edwards, Wolfgang Eggert and Alfons J. Weichenrieder, The Measurement of Firm Ownership and its Effect on Managerial Pay, August 2006

1775 Scott Alan Carson and Thomas N. Maloney, Living Standards in Black and White: Evidence from the Heights of Ohio Prison Inmates, 1829 - 1913, August 2006 
1776 Richard Schmidtke, Two-Sided Markets with Pecuniary and Participation Externalities, August 2006

1777 Ben J. Heijdra and Jenny E. Ligthart, The Transitional Dynamics of Fiscal Policy in Small Open Economies, August 2006

1778 Jay Pil Choi, How Reasonable is the 'Reasonable' Royalty Rate? Damage Rules and Probabilistic Intellectual Property Rights, August 2006

1779 Ludger Woessmann, Efficiency and Equity of European Education and Training Policies, August 2006

1780 Gregory Ponthiere, Growth, Longevity and Public Policy, August 2006

1781 Laszlo Goerke, Corporate and Personal Income Tax Declarations, August 2006

1782 Florian Englmaier, Pablo Guillén, Loreto Llorente, Sander Onderstal and Rupert Sausgruber, The Chopstick Auction: A Study of the Exposure Problem in Multi-Unit Auctions, August 2006

1783 Adam S. Posen and Daniel Popov Gould, Has EMU had any Impact on the Degree of Wage Restraint?, August 2006

1784 Paolo M. Panteghini, A Simple Explanation for the Unfavorable Tax Treatment of Investment Costs, August 2006

1785 Alan J. Auerbach, Why have Corporate Tax Revenues Declined? Another Look, August 2006

1786 Hideshi Itoh and Hodaka Morita, Formal Contracts, Relational Contracts, and the Holdup Problem, August 2006

1787 Rafael Lalive and Alejandra Cattaneo, Social Interactions and Schooling Decisions, August 2006

1788 George Kapetanios, M. Hashem Pesaran and Takashi Yamagata, Panels with Nonstationary Multifactor Error Structures, August 2006

1789 Torben M. Andersen, Increasing Longevity and Social Security Reforms, August 2006

1790 John Whalley, Recent Regional Agreements: Why so many, why so much Variance in Form, why Coming so fast, and where are they Headed?, August 2006 